Sci. Journal of Oct. 6Uni. (SJO6U), ISSN: 2314-8640: Vol.2(1): 67-71, 2014.

sjou.journals.ekb.eg

\title{
Analysis of Road Traffic Accidents on Cairo-Suez Highway in Egypt
}

\author{
"Hassan A. Mahdy, Khaled A. Kandil, Hamdy E. Ebrahim and Amira F. Foda \\ Ain Shams University, Faculty of Engineering, Public Works Department Cairo, Egypt
}

Received: 22-01-2014

Accepted: 10-02-2014

Published:01-03-2014

*Corresponding author: Ain Shams University, Faculty of Engineering, Public Works Department Cairo, Egypt

\begin{abstract}
Transportation is the movement of people and goods from place to other, as a result of the interaction between different social and economical activities in several separate places. So, the main role of traffic engineering is to deal with planning, geometric design and traffic operations for road networks, terminals and lands lie on roads to achieve safe, fast and convenient transportation for people and goods. The main role of transportation for human's life, leads to continuous increase in traffic volumes, which results continuous increase of road traffic accidents, environmental pollution and delays (because of traffic congestions). Increase of road traffic accidents is considered the most dangerous result of increased traffic volumes, as it cause many fatalities, injuries and damaged properties. So, it mainly and directly affects the situation of road traffic safety in Egypt, which became very dangerous during last few years. After collecting traffic data for Cairo - Suez Highway from the Traffic Police Department, Ministry of Interior in Egypt, this paper carries out quantitative statistical analysis of these data and finally, explores a linear regression model between the number of road traffic accidents and the types of vehicles caused these accidents. Data processing is mostly done by SPSS.
\end{abstract}

Key Words: Planning, geometric, design, traffic, road, networks.

\section{Introduction}

Nothing more valuable than human`s life, road traffic accident is one of the leading causes of human`s death. According to Global Status Report on Road Safety Time for Action (2009) by World Health Organization (WHO), there are yearly 1.2 million people die, and about 20 to 50 million people suffer non-fatal injuries on the world's road traffic accidents. In addition, road traffic accidents cost countries up to $4 \%$ of their Gross National Product.

According to the Global Status Report on Road Safety Time for Action (2009) by World Health Organization, approximately $62 \%$ of reported road traffic fatalities occur in 10 countries, which represent $56 \%$ of the world's population. These countries are: India, China, the United States, the Russian Federation, Brazil, Iran, Mexico, Indonesia, South Africa, and Egypt.
Accordin traffic fatalities are as follows:
4) The United States
6) Indonesia
7) The Russian Federation countries with the highest numbers of road

1) China

2) India

3) Nigeria

5) Pakistan

8) Brazil

9) Egypt

10) Ethiopia

According to According to Brief Assessment Report (2007) by the Delegation of the European Commission in Cairo, and Restructuring of Road Safety Division within the Egyptian General Authority for Roads, Bridges, and Land Transport, Egyptian road traffic fatality rate per 100 million driven kilometers is around 43 which above 
similar rates for many Arab and African countries, and at least 10 times higher than the similar rates for the best performing countries in European Union.

According to Injury Surveillance Report (2009) by Egyptian Ministry of Health in collaboration with World Health Organization, road traffic injuries percentage increased from $11.52 \%$ of total injuries in 2001 to $12.87 \%$ of total injuries in 2009 in Egypt.

So, Egypt is in great need to improve its road traffic safety situation as soon as possible, Cairo Suez Highway is considered one of the most dangerous accident prone areas in Egypt, so this paper introduces quantitative statistical analysis for road traffic accidents on it. The collected traffic data represents the situation of road traffic accidents and accidents vehicles types on Cairo Suez Highway in Egypt during years from 2010 to 2011. Quantitative statistical analysis is carried out for finding the correlation between the number of road traffic accidents and the accidents vehicles types (passenger cars, trucks, buses, motorcycles, etc.). On the light of the found correlation, some types of vehicles which have a significant correlation with the number of road traffic accidents are chosen for building the linear regression model between the number of road traffic accidents and the accidents vehicles types. Data processing is mostly done by SPSS.

1. Representing of Collected Traffic Data for Cairo Suez Highway

The number of road traffic accidents and the accidents vehicles types on the Cairo - Suez Highway in Egypt during the period (2010 2011) are shown in Table 1.

Table 1: Number of Road Traffic Accidents according to Accidents Vehicles Types on Cairo - Suez Highway during the Period $(2010-2011)$

\begin{tabular}{|c|c|c|c|}
\hline \multirow{2}{*}{ Accidents Vehicles Types } & \multicolumn{2}{|c|}{ Number of Accidents } & \multirow{2}{*}{ Total } \\
\hline & 2010 & 2011 & \\
\hline 1) Passenger Cars & 158 & 65 & 223 \\
\hline 2) Trucks & 135 & 63 & 198 \\
\hline 3) Buses & 19 & 8 & 27 \\
\hline 4) Taxis and Microbuses & 18 & 9 & 27 \\
\hline 5) Motorcycles & 4 & 0 & 4 \\
\hline 6) Public Service Vehicles & 1 & 0 & 1 \\
\hline 7) Military Vehicles & 8 & 7 & 15 \\
\hline 8) Others & 10 & 2 & 12 \\
\hline Total & 353 & 154 & 507 \\
\hline
\end{tabular}

Source: Traffic Police Department, Ministry of Interior in Egypt

\section{Analysis of Collected Traffic Data for Cairo - Suez Highway during the Period (2010 - 2011)}

The traffic data are analyzed in different stages as follows:

Stage I: Building of correlation matrix

Correlation matrixes are developed of the number of road traffic accidents and the types of licensed vehicles caused these accidents to represent the correlation between road traffic accidents and types of licensed vehicles caused these accidents.

According to the eight built correlation matrixes, the correlation between the total number of road traffic accidents and the types of licensed vehicles caused these accidents are classified to significant and nonsignificant correlation, as shown in Table 2.

Table 2: Calibration Results of the Eight Built Correlation Matrixes

\begin{tabular}{|c|c|c|c|}
\hline $\begin{array}{c}\text { Accidents } \\
\text { Vehicles Types }\end{array}$ & $\begin{array}{c}\text { Significance } \\
\text { Coefficient } \\
\text { (2-talied) }\end{array}$ & $\begin{array}{c}\text { Pearson } \\
\text { Correlation } \\
\text { Coefficient }\end{array}$ & $\begin{array}{c}\text { Correlation } \\
\text { Type }\end{array}$ \\
\hline $\begin{array}{ll}\text { 1) } & \text { Passenger } \\
& \text { Cars }\end{array}$ & 0.000 & $0.919^{* *}$ & Significant \\
\hline 2) $\quad$ Trucks & 0.000 & 0.891 ** & Significant \\
\hline 3) Buses & 0.016 & $0.488^{*}$ & Significant \\
\hline $\begin{array}{l}\text { 4) } \\
\text { Taxis and } \\
\text { Microbuses }\end{array}$ & 0.009 & $0.519^{* *}$ & Significant \\
\hline 5) Motorcycles & 0.097 & 0.347 & $\begin{array}{c}\text { Non- } \\
\text { Significant }\end{array}$ \\
\hline 6) $\begin{array}{l}\text { Public } \\
\text { Service } \\
\text { Vehicles }\end{array}$ & 0.435 & 0.167 & $\begin{array}{c}\text { Non- } \\
\text { Significant }\end{array}$ \\
\hline $\begin{array}{l}\text { 7) } \quad \text { Military } \\
\text { Vehicles }\end{array}$ & 0.627 & 0.104 & $\begin{array}{c}\text { Non- } \\
\text { Significant }\end{array}$ \\
\hline 8) Others & 0.000 & $0.675^{* *}$ & Significant \\
\hline
\end{tabular}

**. Correlation is significant at the 0.01 level (2-tailed)

*. Correlation is significant at the 0.05 level (2-tailed)

According to Table 2, motorcycles, public service vehicles, and military vehicles are the neglected types in building the linear regression model. Because of the nonsignificant correlation between them and the total number of road traffic accidents.

Stage II: Building of linear regression model In order to find the relation between the total number of road traffic accidents and the accidents vehicles types, linear regression 
model is developed between the total number of road traffic accidents and the number of accidents caused by licensed vehicles of selected types in stage I.

The output for the multiple linear regression is shown in Table 4.

Table 3: Coefficients Output for Multiple Linear Regression

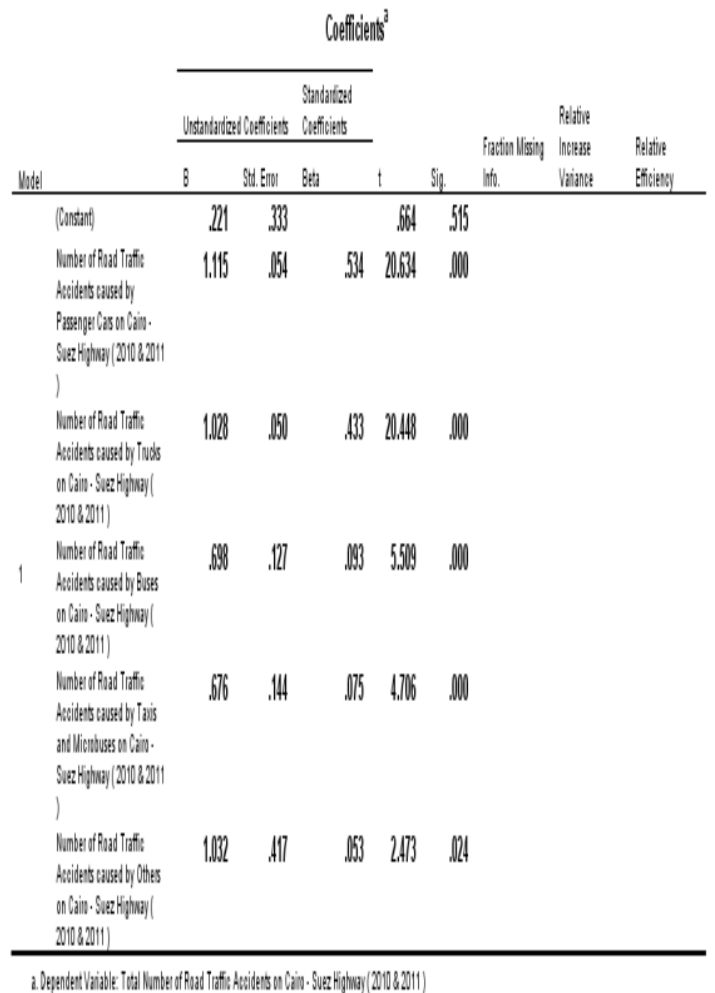

According to Table 3, there are four coefficients are studied to finally set the linear regression model. These coefficients are as follows:
a) Standerized Coefficients (Beta)
b) (t) Coefficients
c) Significance Coefficients
d) Unstanderized Coefficients (B)

Table 4. Represents the ranks of accidents vehicles types according to their effect on the number of road traffic accidents, as the Standerized Coefficients (Beta) measure the weight of the effect of the accidents vehicles of each type separately on the number of road traffic accidents, in case of neglecting the effect of the other types.
Table 4: Ranks of Accidents Vehicles Types according to their Effect on the Total Number of Road Traffic Accidents

\begin{tabular}{|c|c|c|}
\hline $\begin{array}{c}\text { Accidents Vehicles } \\
\text { Types }\end{array}$ & $\begin{array}{c}\text { Standardized } \\
\text { Coefficients } \\
\text { (Beta) }\end{array}$ & $\begin{array}{c}\text { Rank of } \\
\text { Licensed } \\
\text { Vehicle } \\
\text { Type }\end{array}$ \\
\hline $\begin{array}{l}\text { 1) Passenger } \\
\text { Cars }\end{array}$ & 0.534 & 1 \\
\hline 2) Trucks & 0.433 & 2 \\
\hline 3) Buses & 0.093 & 3 \\
\hline $\begin{array}{l}\text { 4) Taxis and } \\
\text { Microbuses }\end{array}$ & 0.075 & 4 \\
\hline 5) Others & 0.053 & 5 \\
\hline
\end{tabular}

Table 5. Represents (t) Coefficients, which inform to accept or reject the null hypothesis, which means that there is no effect of the accidents vehicles types on the number of road traffic accidents.

Table 5: (t) Coefficients of Accidents Vehicles Types

\begin{tabular}{|c|c|c|}
\hline Independent Variable & $\begin{array}{c}(\mathrm{t}) \\
\text { Coefficients }\end{array}$ & $\begin{array}{c}\text { Accept or } \\
\text { Reject Null } \\
\text { Hypothesis }\end{array}$ \\
\hline Constant & $\begin{array}{c}0.664< \\
2.069\end{array}$ & Accept \\
\hline $\begin{array}{l}\text { 1) Passenger } \\
\text { Cars }\end{array}$ & $\begin{array}{c}20.634> \\
2.069\end{array}$ & Reject \\
\hline 2) Trucks & $\begin{array}{c}20.488> \\
2.069\end{array}$ & Reject \\
\hline 3) Buses & $\begin{array}{c}5.509> \\
2.069\end{array}$ & Reject \\
\hline $\begin{array}{l}\text { 4) Taxis and } \\
\text { Microbuses }\end{array}$ & $\begin{array}{c}4.706> \\
2.069\end{array}$ & Reject \\
\hline 5) Others & $\begin{array}{c}2.473> \\
2.069\end{array}$ & Reject \\
\hline
\end{tabular}


Table 6. Represents Significance Coefficients, which inform if the accidents vehicles types have significant or nonsignificant effect on the number of road traffic accidents.

Table 6: Significance Coefficients of Accidents Vehicles Types

\begin{tabular}{|c|c|c|}
\hline $\begin{array}{l}\text { Independent } \\
\text { Variable }\end{array}$ & $\begin{array}{l}\text { Significance } \\
\text { Coefficients }\end{array}$ & $\begin{array}{c}\text { Effect of } \\
\text { Licensed } \\
\text { Vehicle Type } \\
\end{array}$ \\
\hline Constant & 0.515 & $\begin{array}{l}\text { Non- } \\
\text { Significant }\end{array}$ \\
\hline $\begin{array}{l}\text { 1) Passenger } \\
\text { Cars }\end{array}$ & 0.000 & Significant \\
\hline 2) Trucks & 0.000 & Significant \\
\hline 3) Buses & 0.000 & Significant \\
\hline $\begin{array}{ll}4) & \text { Taxis and } \\
& \text { Microbuses } \\
\end{array}$ & 0.000 & Significant \\
\hline 5) Others & 0.024 & Significant \\
\hline
\end{tabular}

Effect is significant at the 0.01 or 0.05 level.

According to Tables (5\&6), all types of accidents vehicles have a significant effect on the number of road traffic accidents, and the constant is the only neglected independent variable. Table 7. Represents Unstandardized Coefficients (B), which represent the coefficients of the multiple linear regression model, which consist of the constant and the intercepts of each of the accidents vehicles types.

Table 7: Unstandardized Coefficients (B) of Accidents Vehicles Types

\begin{tabular}{|c|c|}
\hline Accidents Vehicles Types & $\begin{array}{l}\text { Unstandardized } \\
\text { Coefficients (B) }\end{array}$ \\
\hline Passenger Cars & 1.115 \\
\hline 2) Trucks & 1.028 \\
\hline 3) Buses & 0.698 \\
\hline $\begin{array}{l}\text { 4) Taxis and } \\
\text { Microbuses }\end{array}$ & 0.676 \\
\hline 5) Others & 1.032 \\
\hline
\end{tabular}

Stage III: Setting of the multiple linear regression model

Finally, the multiple linear regression model for the number of road traffic accidents on the Cairo - Suez Highway:

No. of Road Traffic Accidents

$=1.115$ (P.C. $)+1.028(\mathrm{~T})+0.698(\mathrm{~B})+$

$0.676(\mathrm{Ta} \& \mathrm{Mi})+1.032(\mathrm{O})$

As,

$($ P.C. $)=$ Passenger Cars, $(\mathrm{T})=$ Trucks, $(\mathrm{B})=$ Buses,

(Ta \& Mi) $=$ Taxis and Microbuses, $(\mathrm{O})=$ Others

Note, the required numbers are the numbers of road traffic accidents caused by licensed vehicles of all mentioned types.

\section{Interpretation of Results}

Quantitative statistical analysis for the traffic data for Cairo - Suez Highway in Egypt which consists of the number of road traffic accidents and accidents vehicles types during the period $(2010-2011)$ found that there are some types of accidents vehicles can be used to predict the number of road traffic accidents according to the number of accidents they caused. These types are passenger cars, trucks, buses, taxis, microbuses, and other vehicles. Other types of licensed vehicles can be neglected in the prediction of the number of road traffic accidents on Cairo - Suez Highway.

\section{Conclusion}

According to the final multiple linear regression model for the number of road traffic accidents on the Cairo - Suez Highway, the following results are found:

1. The effect of trucks equal 0.92 times of the effect of passenger cars on the total number of road traffic accidents on Cairo - Suez Highway in Egypt.

2.The effect of buses equal 0.63 times of the effect of passenger cars on the total number of road traffic accidents on Cairo - Suez Highway in Egypt.

3 . The effect of taxis and microbuses equal 0.61 times of the effect of passenger cars on the total number of road traffic accidents on Cairo - Suez Highway in Egypt.

4.The effect of other vehicles equal 0.93 times of the effect of passenger cars on the total number of road traffic accidents on Cairo - Suez Highway in Egypt. 


\section{Recommendations}

1) Increasing the availability of mass transit to reduce the number of private cars. So, numbers of road traffic accidents occur due to private cars, motorcycles will decrease.

2)Separating trucks from other traffic by any method of the following:

a) Truck Lane Restrictions. (Trucks restricted from specified lanes.)

b) Truck Only Lane. (Trucks dedicated lanes are specified.)

c) Truck Only Time. (Trucks dedicated time of the day is specified.)

d) Truck Bypass. (Trucks use alternative route to bypass the congested roads.)

3) Separating buses from other traffic into specified roadside bus lanes.

So, number of road traffic accidents causes due to buses will reduce.

4) Restrictions of speed limit, as for every $1 \mathrm{~km} / \mathrm{hr}$ reduction in average speed; there is a $2 \%$ reduction in the number of road traffic accidents, according to World Health Organization facts.

5) Restrictions of drink-driving, as it could reduce alcohol-related road traffic accidents by $20 \%$, according to World Health Organization facts.

6) Mandatory use of seat-belt, as it could reduce the risk of death in a road traffic accident by $61 \%$, according to World Health Organization facts.

\section{References}

"Global Status Report on Road Safety Time for Action.", 2009, World Health Organization (WHO), Department of Violence \& Injury Prevention \& Disability (VIP).

"Brief Assessment Report.", 2007. The Delegation of the European Commission in Cairo, and Restructuring of Road Safety Division within the Egyptian General Authority for Roads, Bridges, and Land Transport.

"Injury Surveillance Report." 2009, Egyptian Ministry of Health in collaboration with World Health Organization (WHO). 